Laser Chem. 1988, Vol. 9, pp. 401-416

(C) 1988 Harwood Academic Publishers GmbH

Photocopying permitted by license only

Reprints available directly from the Publisher

Printed in the United Kingdom

\title{
Surface-Enhanced Raman Spectroscopy of Thionine-modified Gold Electrodes
}

\author{
H. R. VIRDEE and R. E. HESTER \\ Department of Chemistry, University of York, Heslington, York Y01 5DD
}

(Received 20 May, 1988)

Surface enhanced Raman (SER) and resonance Raman (SERR) techniques have been used in situ to investigate thionine-modified gold electrodes. New surface roughening procedures for gold electrodes have resulted in an order of magnitude increase in the Raman signals. As a result of this, Raman spectra from leucothionine have been observed for the first time. The surface Raman spectra of both thionine and leucothionine are essentially unchanged over the $\mathrm{pH}$ range from 1.3 to 7 but both show major changes at $\mathrm{pH} 10$. This behaviour has been related to changes in the absorption spectrum of thionine at $\mathrm{pH} 1.0$ where the compound is believed to exist as thionine hydroxide. At pH 1.3 and 7 the Raman signals from thionine arise from a combination of surface enhancement and resonance enhancement processes, whereas signals from leucothionine arise solely from surface enhancement. At pH 10 surface enhancement processes give rise to Raman intensity for both thionine and leucothionine.

KEY WORDS: Raman spectroscopy, SERS, SERRS, thionine, modified electrodes, resonance Raman.

\section{INTRODUCTION}

Electrode surfaces modified by the immobilization of electrochemically active species have attracted considerable research interest in recent years, ${ }^{1}$ mainly because of their promise in applications to such processes as electrocatalysis ${ }^{2}$ and solar energy conversion. ${ }^{3}$ One such 
system that has been investigated extensively by both electrochemical $^{4-8}$ and spectroscopic techniques ${ }^{9,10}$ involves thioninemodified electrodes.

The thionine redox couple in aqueous acid solution may be represented as follows:

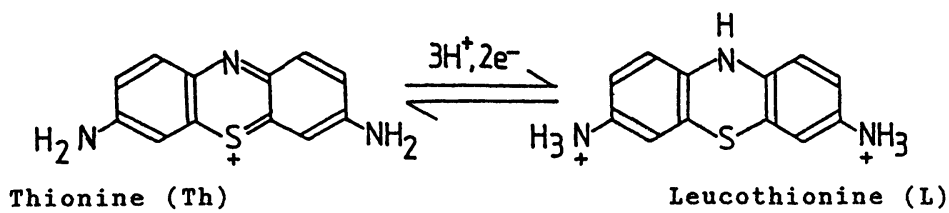

Thionine may be electrochemically coated ${ }^{4,5}$ onto substrates such as platinum and gold at oxidizing potentials, thus producing thioninemodified electrodes. The thionine coat formed on the electrode surface is electroactive and can be switched between leucothionine and thionine forms. Electrochemical ${ }^{6,7}$ and $\mathrm{x}$-ray photoelectron spectroscopic studies ${ }^{9}$ have suggested that thionine is dimerized on the electrode surface.

More recently, in this laboratory, surface enhanced Raman spectroscopy (SERS) and surface enhanced resonance Raman spectroscopy (SERRS) ${ }^{10}$ have been applied, in situ, to the study of thioninemodified gold electrodes in acid electrolyte solution. In that work good quality Raman spectra were observed from the coated thionine. However, no Raman spectra of leucothionine could be observed. The Raman spectrum of coated thionine ${ }^{10}$ showed additional bands that were not present in the spectrum of solid thionine. The bands have been attributed to the bridging $\mathrm{C}-\mathrm{N}-\mathrm{C}$ bonds in the thionine dimer formed on the elctrode surface.

In this work we present further SERRS and SERS results from thionine and leucothionine on gold electrodes at various $\mathrm{pH}$ values.

\section{EXPERIMENTAL}

Thionine used in this work was from Fluka and was purified by column chromatography on alumina, washed with chloroform and acetone and dried in vacuo at room temperature. Sulphuric acid was laboratory reagent grade from BDH. Sodium hydroxide and potassium chloride 
were from Fisons. All the solutions were prepared in distilled water. The electrolyte solutions were deoxygenated by bubbling $\mathrm{N}_{2}$ for about half an hour prior to the spectroelectrochemical measurements.

The details of the Raman spectroelectrochemical cell, with a rotating electrode, are given elsewhere.$^{14}$ An Oxford Electrodes potentiostat was used for the control of potential. A Hewlett-Packard model $70158 \mathrm{X}-$ Y recorder was used for recording the cyclic voltammograms. All the potentials were measured and are reported with respect to a saturated calomel reference electrode (SCE). The gold working electrode used in this work consisted of a $c a .7 \mathrm{~mm}$ diameter cylindrical disc, $c a .5 \mathrm{~mm}$ thick, embedded in a Teflon sleeve which was attached to a rotating shaft assembly. The exposed area of the working electrode was $0.385 \mathrm{~cm}^{2}$. For all the Raman measurements the working electrode was rotated at $c a .3700$ r.p.m.

Raman spectra were recorded on a Spex model 1403 spectrometer fitted with a cooled photomultiplier, RCA type C31034-A02, and linked to a Spex DPC-2 digital photometer. A compudrive unit and Scamp minicomputer controlled the instrument. Radiation for exciting the Raman spectra was provided by a Spectra Physics model 170 krypton ion laser. In all experiments the $647.1 \mathrm{~nm}$ line was used to excite the Raman spectra and the laser power used was ca. $100 \mathrm{~mW}$ at the sample. Spectra were recorded with a spectral band pass of $5 \mathrm{~cm}^{-1}$. The scattered light was collected at $90^{\circ}$ to the incident laser beam which was itself polarized perpendicular to the scattering plane. The working electrode surface was parallel to the cell window and was set at $c a .50-60^{\circ}$ with respect to the laser beam.

A roughening procedure for the gold electrode, similar to that described recently by Weaver et al. ${ }^{11-13}$ was used prior to the coating of the electrode with thionine. The working gold electrode was polished to a mirror finish with a slurry of alumina polishing powder (Banner Scientific) in distilled water. The electrode was rinsed with distilled water. The Raman spectroelectrochemical cell together with the working electrode was then assembled and fitted with $1 \mathrm{~mol} \mathrm{dm}^{-3}$ $\mathrm{KCl}$ solution in distilled water. After deoxygenating for $c a .0 .5$ hour the oxidation/reduction cycles (ORCs) were then carried out between the potential limits of $-0.20 \mathrm{~V}$ to $+1.10 \mathrm{~V}$ (SCE) at a sweep rate of $0.05 \mathrm{~V} \mathrm{~s}^{-1}$. It was found that $c a$. 25 ORCs were necessary for the activation of the gold electrode for optimal surface enhancement.

After the ORCs had been carried out the $\mathrm{KCl}$ solution was removed 
and the cell was rinsed with distilled water, followed by a rinse with a saturated solution of thionine in $0.05 \mathrm{~mol} \mathrm{dm}^{-3} \mathrm{H}_{2} \mathrm{SO}_{4}$. The cell was then filled with thionine solution and the gold electrode was coated ${ }^{4}$ at $1.15 \mathrm{~V}$ for 10 minutes. Finally, the thionine solution was removed from the cell and the whole system rinsed with distilled water. Raman spectra of coated thionine were then recorded in $0.05 \mathrm{~mol} \mathrm{dm}^{-3} \mathrm{H}_{2} \mathrm{SO}_{4}$ solution at open circuit potential $0.33 \mathrm{~V}$ (SCE) using $647.1 \mathrm{~nm}$ excitation. The cell was then brought under potential control and the cyclic voltammogram of coated thionine was recorded in the potential range $+0.5 \mathrm{~V}$ to $-0.20 \mathrm{~V}$. A typical cyclic voltammogram from a thionine coated gold electrode in acid solution is shown in Figure 1. Raman spectra of coated thionine were recorded at various applied potentials in the range -0.20 to $+0.40 \mathrm{~V}$.

Raman spectra of coated thionine in contact with electrolyte solution at $\mathrm{pH} 7$ and 10 were also recorded. In these cases the $\mathrm{pH}$ of the original $0.05 \mathrm{~mol} \mathrm{dm} \mathrm{dm}^{-3} \mathrm{H}_{2} \mathrm{SO}_{4}$ solution was changed by adding a concentrated solution of $\mathrm{NaOH}$ dropwise until the required $\mathrm{pH}$ was reached. A typical cyclic voltammogram of the thionine modified electrode at pH 10 is shown in Figure 1. At pH 7, Raman spectra at

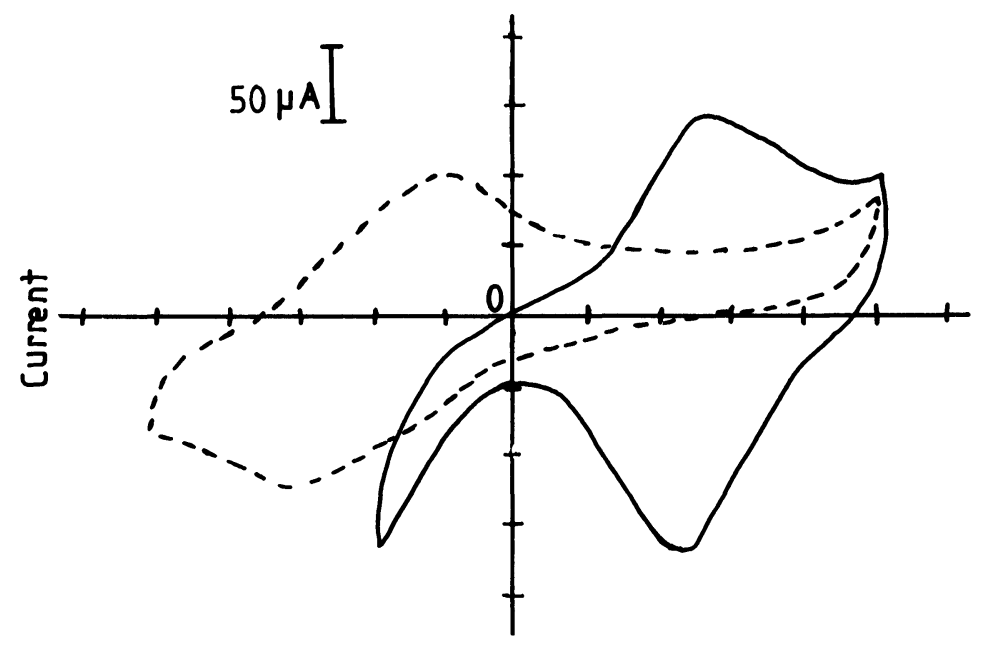

$\stackrel{0.1 \mathrm{~V}}{\longmapsto}$

Potential

Figure 1 Cyclic voltammogram of thionine-coated gold electrode at $\mathrm{pH}=1.3$ (solid line) and $\mathrm{pH}=10$ (broken line); sweep rate $0.05 \mathrm{~V} \mathrm{~s}^{-1}$. 
applied potentials of +0.30 and $-0.20 \mathrm{~V}$ were recorded. At $\mathrm{pH} 10$, Raman spectra at various applied potentials in the range -0.50 to $+0.30 \mathrm{~V}$ were recorded.

\section{RESULTS AND DISCUSSION}

Raman spectra of thionine-coated gold electrodes in contact with electrolyte solutions at $\mathrm{pH} 1.3,7$ and 10 have been measured at various applied potentials. For these measurements the gold electrode was activated for surface enhanced Raman scattering prior to coating with thionine. In general very much stronger Raman signals were observed from the electrode surface than previously reported. ${ }^{10}$

\section{(a) $\mathrm{pH} 1.3$}

SERR spectra of thionine, coated on gold electrodes, in $0.05 \mathrm{~mol} \mathrm{dm}^{-3}$ $\mathrm{H}_{2} \mathrm{SO}_{4}(\mathrm{pH}$ 1.3) at various applied potentials are shown in Figure 2. Also shown in this figure is the Raman spectrum from the thioninecoated dry electrode. The wavenumber shifts and the relative intensities of the bands observed in these spectra are given in Table I. Raman spectra shown in Figure 2 were recorded in sequence from A to E.

In general there is a good agreement between these Raman spectra and those reported in Ref. 10. The main difference is that in the present work much higher Raman signals $\left(100 \mathrm{k}\right.$ counts s $^{-1}$ compared with $1-5 \mathrm{k}$ counts $\mathrm{s}^{-1}$ ) were obtained using the multiple oxidation reduction cycles. In the previous Raman spectroscopic study of the thionine/Au system, the Raman spectrum from the leucothionine form of the coated electrode could not be measured. Because leucothionine does not absorb at the wavelength of excitation, no resonance enhancement of the Raman spectrum occurs and there was previously very little contribution from the SER processes. In the present work Raman spectra from leucothionine could be observed, although the Raman signal was an order of magnitude lower than that from the thionine form. Since leucothionine does not absorb in the visible region of the spectrum, the Raman intensity for leucothionine is purely derived from the surface enhancement processes.

Figure 2A shows the SERRS of thionine coated on an Au electrode immediately after the coating procedure, i.e. no electrochemistry had 


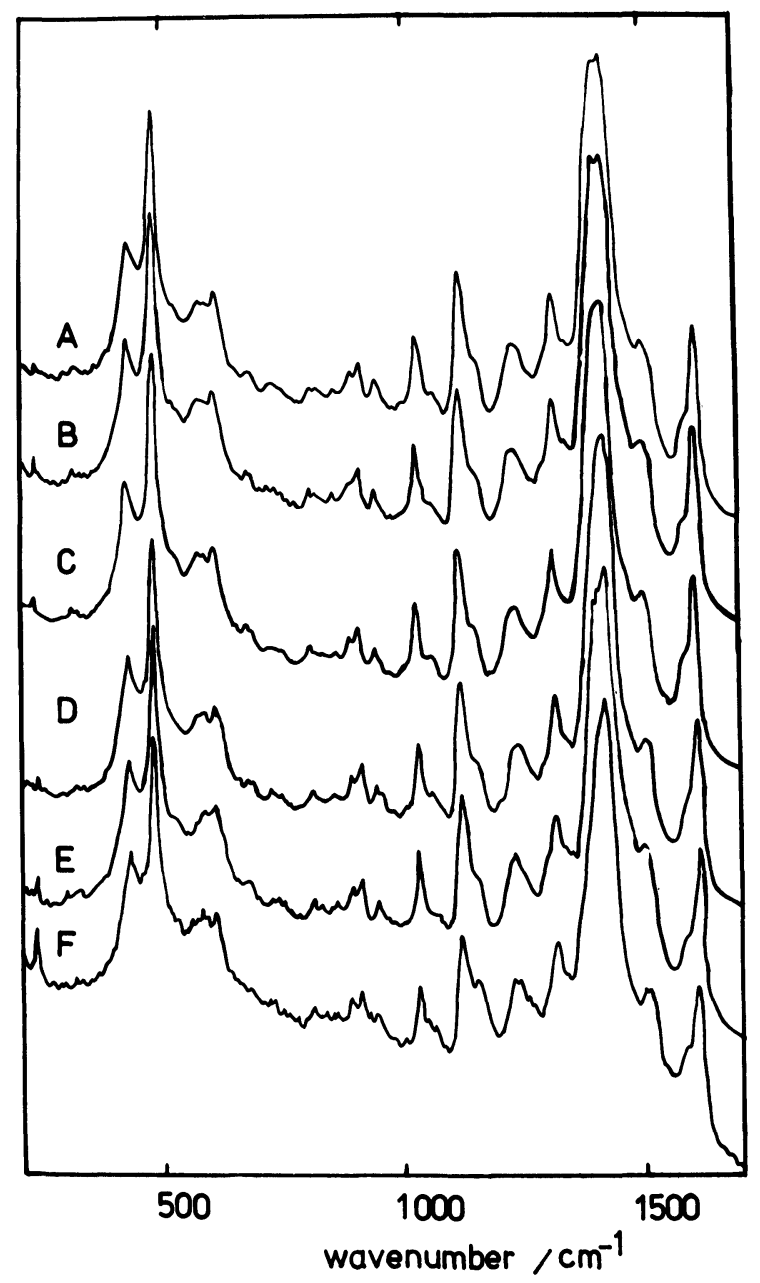

Figure 2 SERRS and SERS of thionine-coated gold electrode at $\mathrm{pH} 1.3$, at various applied potentials. (A) Open circuit potential $(-0.28 \mathrm{~V})$ immediately after coating; (B) Spectrum recorded after measuring a cyclic voltammogram; (C) Spectrum at $-0.20 \mathrm{~V}$ (expanded $\times 10$ ); (D) Spectrum at $+0.40 \mathrm{~V}$; (E) Spectrum from a dry electrode. 
Table I Band wavenumbers $\left(\mathrm{cm}^{-1}\right)$ in SERRS and SERS of thionine-modified gold electrode at $\mathrm{pH} 1.3$ at various applied potentials. $6471 \mathrm{~nm}$ excitation.

\begin{tabular}{|c|c|c|c|c|}
\hline $\begin{array}{l}\text { Open circuit } \\
\text { voltage }(+0.28 \\
\text { V) immediately } \\
\text { after coating } \\
\text { (thionine) }\end{array}$ & $\begin{array}{l}\text { Open circuit } \\
\text { voltage }(+0.28 \\
\text { V) after cycling } \\
\text { between }-0.2 \\
\text { and } 0.5 \mathrm{~V} \\
\text { (thionine) }\end{array}$ & $\begin{array}{l}-0.20 \mathrm{~V} \\
\text { (leucothionine) }\end{array}$ & $\begin{array}{l}+0.40 \mathrm{~V} \\
\text { (thionine) }\end{array}$ & $\begin{array}{l}\text { Dry electrode } \\
\text { (thionine) }\end{array}$ \\
\hline 1619(s) & 1619(s) & $\begin{array}{l}1618(\mathrm{sh}) \\
1609(\mathrm{w}) \\
1581(\mathrm{w}) \\
1563(\mathrm{w})\end{array}$ & 1619(s) & $1618(s)$ \\
\hline 1503(s) & $1503(\mathrm{~s})$ & $1502(\mathrm{sh})$ & $1501(\mathrm{~s})$ & $1500(\mathrm{~s})$ \\
\hline 1480 (sh) & 1479(sh) & $1490(w)$ & 1480 (sh) & $1480(\mathrm{sh})$ \\
\hline 1426 (sh) & 1423(sh) & $1425(\mathrm{sh})$ & 1423(sh) & \\
\hline 1392(vs) & 1393(vs) & $1390(w)$ & 1392(vs) & 1391(vs) \\
\hline 1319(w) & $1320(w)$ & $1318(\mathrm{vw})$ & 1319(w) & 1314(w) \\
\hline 1291(w) & 1292(sh) & & 1292(w) & 1293(sh) \\
\hline $1223(w)$ & $1235(\mathrm{w})$ & $1240(\mathrm{~m})$ & 1233(vw) & $1235(\mathrm{w})$ \\
\hline 1150 (sh) & 1151(m) & $1152(\mathrm{~m})$ & $1152(\mathrm{~m})$ & $1150(\mathrm{~m})$ \\
\hline $1130(\mathrm{~m})$ & 1132(sh) & 1119 & $1135(\mathrm{sh})$ & $1135(\mathrm{sh})$ \\
\hline 1038(m) & 1038(m) & $1036(\mathrm{vw})$ & $1038(\mathrm{~m})$ & 1036(m) \\
\hline $1003(\mathrm{vw})$ & $1003(w)$ & & $1003(\mathrm{vw})$ & $1005(\mathrm{vw})$ \\
\hline $953(w)$ & 950 & & $955(\mathrm{vw})$ & $960(\mathrm{w})$ \\
\hline 911(m) & 911(m) & $909(\mathrm{vw})$ & 911(w) & $909(\mathrm{~m})$ \\
\hline $885(\mathrm{~m})$ & $883(\mathrm{sh})$ & & $888(\mathrm{sh})$ & \\
\hline $825(\mathrm{vw})$ & $828(\mathrm{sh})$ & & $828(\mathrm{sh})$ & $829(w-m)$ \\
\hline 807(m) & $810(w)$ & $813(w)$ & 811(m) & $\begin{array}{l}803(w-m) \\
760(v w)\end{array}$ \\
\hline $750(\mathrm{sh})$ & $752(\mathrm{sh})$ & & $750(\mathrm{vw})$ & $748(\mathrm{vw})$ \\
\hline 730 (vw) & $734(w)$ & & 735 (vw) & 733(vw) \\
\hline 681(w) & $680(w)$ & & $680(\mathrm{w})$ & $680(w)$ \\
\hline $616(\mathrm{~m})$ & $616(s)$ & $616(\mathrm{~m})$ & 614(s) & $614(s)$ \\
\hline 481(vvs) & 481(vvs) & 486 (vs) & 481(vvs) & 481(vvs) \\
\hline $428(\mathrm{sh})$ & 441(sh) & 442(sh) & $440(\mathrm{sh})$ & 439 (sh) \\
\hline & 419(sh) & 420 (sh) & 419(sh) & $418(\mathrm{sh})$ \\
\hline $402(\mathrm{~m})$ & 399(sh) & 399(sh) & $400(\mathrm{sh})$ & $398(\mathrm{sh})$ \\
\hline $314(v w)$ & $316(\mathrm{vw})$ & $313(v w)$ & $315(\mathrm{vw})$ & $315(\mathrm{vw})$ \\
\hline 295(vw) & 296(vw) & & 296(vw) & 297(vw) \\
\hline
\end{tabular}

Key: $\mathrm{s}=$ strong, $\mathrm{m}=$ medium, $\mathrm{v}=$ very, $\mathrm{sh}=$ shoulder, $\mathrm{w}=$ weak.

been carried out with this electrode. This spectrum is in good agreement with that previously reported for thionine coated on a gold electrode.$^{10}$ However, there are extra bands at $c a .825,750,730$ and $295 \mathrm{~cm}^{-1}$, relatively weak in intensity.

Spectrum B in Figure 2 was recorded after measuring the cyclic 
voltammogram in the potential range 0.50 to $-0.20 \mathrm{~V}$ and removing the applied voltage. Thus both spectra, $2 \mathrm{~A}$ and $\mathrm{B}$, were measured at the open circuit potential $(+0.28 \mathrm{~V})$ for the thionine coated gold electrode in contact with $0.05 \mathrm{~mol} \mathrm{dm}^{-3} \mathrm{H}_{2} \mathrm{SO}_{4}$. There are a number of irreversible changes seen in spectrum $2 \mathrm{~B}$. In each case the Raman spectrum is dominated by the intense band at $480 \mathrm{~cm}^{-1}$ (assigned to a CNC skeletal deformation mode ${ }^{10}$ ). In spectrum $2 \mathrm{~A}$ a band at 400 $\mathrm{cm}^{-1}$ (assigned to CSC skeletal deformation ${ }^{10}$ ) and a weak shoulder at $428 \mathrm{~cm}^{-1}$ are observed). However, in spectrum $2 \mathrm{~B}$ there are three bands that can be clearly seen on the lower wavenumber side of the main $480 \mathrm{~cm}^{-1}$ band. These bands, at 440,419 and $399 \mathrm{~cm}^{-1}$, appear as weak shoulders. The shape of the complex band structure at $c a .1400$ $\mathrm{cm}^{-1}$ shows a marked difference on cycling between 0.50 and $-0.20 \mathrm{~V}$. For example, in spectrum $2 \mathrm{~A}$ a shoulder at $1425 \mathrm{~cm}^{-1}$ to the main band at $1390 \mathrm{~cm}^{-1}$ appears almost as a doublet. After cycling between 0.50 and $-0.20 \mathrm{~V}$ (spectrum 2B) there is a marked decrease in the relative intensity of this $1425 \mathrm{~cm}^{-1}$ shoulder. This band has been attributed to a $\mathrm{C}-\mathrm{N}$ stretching vibration mode of the amino nitrogen atom bridging the two thionine molecules in the dimer formed on coating. ${ }^{10}$ The wavenumber of $1425 \mathrm{~cm}^{-1}$ is somewhat higher than that expected for a $v$ (asym) $(\mathrm{CN})$ vibration mode and probably reflects some increase in the bond order and/or mode coupling. This "effect" appears to decrease on cycling the voltage of the modified electrode and hence the relative intensity of the $1425 \mathrm{~cm}^{-1}$ band appears to decrease.

Application of further potential and cycling does not affect the appearance of the Raman spectrum (c.f. 2B and 2D). The irreversible changes in appearance of SERRS of thionine on the gold electrode indicate that some type of reorganization of thionine layers on the surface occurs when the applied voltage is cycled after the coating procedure. This reorganization may lower the symmetry of the adsorbed thionine such that bands that were previously Raman inactive become active.

The leucothionine SER spectrum (2C) is markedly different from the SERRS of thionine. As has been stated earlier, the spectrum is an order of magnitude weaker than the SERRS of thionine under the same experimental conditions. This is attributable to the loss of the resonance enhanced contribution to the Raman intensity in the case of leucothionine. The bands that were very low in intensity in the thionine Raman spectrum are not apparent in the leucothionine 
spectrum. However, there are new bands seen at ca. 1609, 1581 and $563 \mathrm{~cm}^{-1}$. The $480 \mathrm{~cm}^{-1}$ band remains the most prominent feature in the Raman spectrum of leucothionine. A band at $1618 \mathrm{~cm}^{-1}$ appears as a weak shoulder to the main band at $1609 \mathrm{~cm}^{-1}$. This whole band structure appears to be somewhat broader than the corresponding band at $1618 \mathrm{~cm}^{-1}$ in the thionine spectrum. The leucothionine band at $1490 \mathrm{~cm}^{-1}$ is to be compared with that from thionine at $1480 \mathrm{~cm}^{-1}$.

Other leucothionine bands occur at 1240 and $1119 \mathrm{~cm}^{-1}$. The corresponding bands in the thionine spectrum are observed at 1235 and $1130 \mathrm{~cm}^{-1}$. Furthermore, a band at $1290 \mathrm{~cm}^{-1}$ in the Raman spectrum of thionine is absent from the leucothionine spectrum.

Spectrum $D$ in Figure 2 was obtained on switching the potential of a thionine-coated electrode to +0.40 from $-0.20 \mathrm{~V}$. The overall intensity of this spectrum was similar to that observed in spectra $2 \mathrm{~A}$ abd $\mathrm{B}$. All the bands present in spectrum $2 \mathrm{~B}$ are also present in spectrum 2D, and with very similar relative intensities.

\section{(b) pH 7}

Raman spectra from a thionine-coated gold electrode, in contact with the electrolyte solution at $\mathrm{pH} 7$ at applied potentials of $+0.30 \mathrm{~V},-0.20$ $\mathrm{V}$, and at the open circuit potential $(+0.28 \mathrm{~V})$ are shown in Figure 3. The sequence of recording these spectra was from $\mathrm{A}$ to $\mathrm{C}$. The positions and the relative intensities of the bands observed in these spectra are given in Table II.

The Raman spectra from coated thionine at $\mathrm{pH} 7$ are very similar to those observed at $\mathrm{pH}$ 1.3. Spectrum A in Figure 3 was measured at the open circuit potential. Here, bands in the $1500-1400 \mathrm{~cm}^{-1}$ region are at lower wavenumbers than those observed in the corresponding spectrum at $\mathrm{pH}$ 1.3. For example, a strong band seen at $1503 \mathrm{~cm}^{-1}$ in the Raman spectrum at pH 1.3 is shifted to $1499 \mathrm{~cm}^{-1}$ at pH 7. Similarly a band at $1425 \mathrm{~cm}^{-1}$ in the Raman spectrum at pH 1.3 shifts to $1420 \mathrm{~cm}^{-1}$ at $\mathrm{pH} 7$.

At an applied potential of $-0.2 \mathrm{~V}$, the overall intensity of the Raman spectrum at pH 7 (spectrum B in Figure 3) goes down by an order of magnitude, just as it does in the Raman spectrum at pH 1.3. This spectrum is attributed to leucothionine. Again the band at 480 $\mathrm{cm}^{-1}$ is the most prominent feature in this spectrum. As at $\mathrm{pH} 1.3$, additional bands at 1609,1524 and $1350 \mathrm{~cm}^{-1}$ are found in the Raman spectrum of leucothionine at $\mathrm{pH}$ 7. These bands are not observed in 


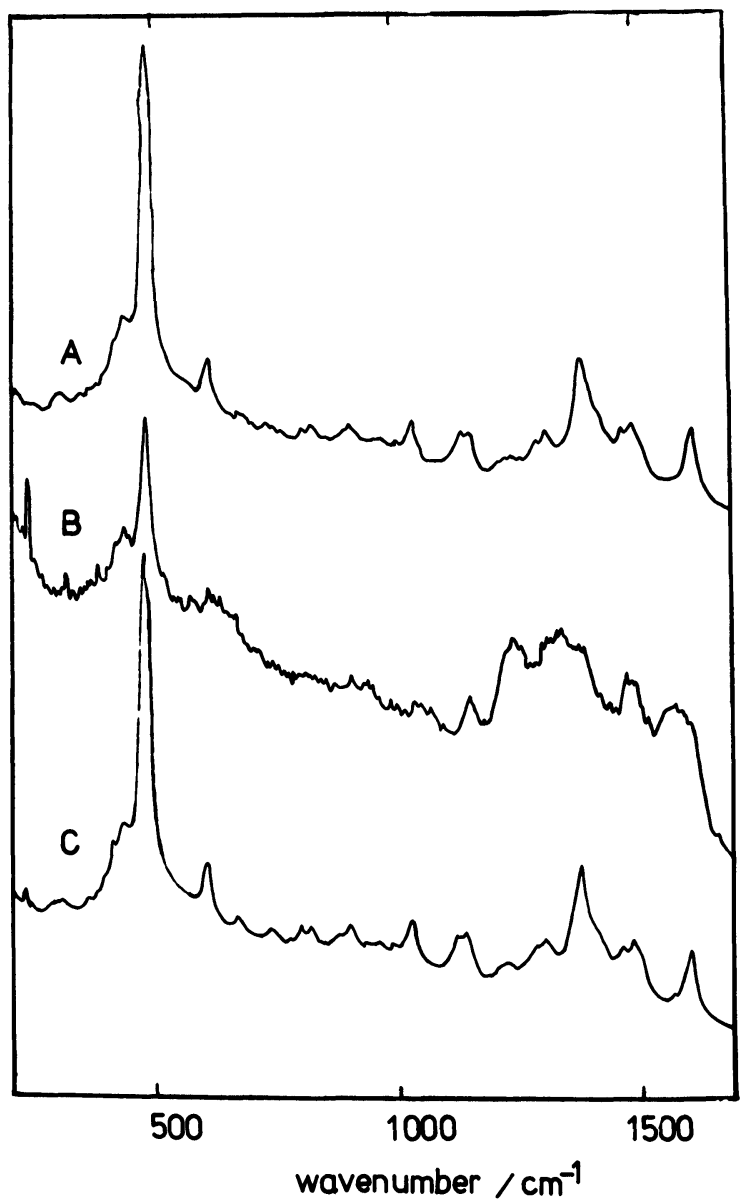

Figure 3 SERRS and SERS of thionine-coated gold electrode at $\mathrm{pH}=7$ at various applied potentials. (A) Open circuit potential $(+0.28 \mathrm{~V})$; $(\mathrm{B})-0.20 \mathrm{~V}$ (spectrum expanded $\times 10) ;(C)+0.30 \mathrm{~V}$.

the spectrum of thionine at this $\mathrm{pH}$. The band at $1480 \mathrm{~cm}^{-1}$ in the thionine spectrum at this $\mathrm{pH}$ is shifted to $c a .1490 \mathrm{~cm}^{-1}$ in the leucothionine spectrum. In general the bands in the $1300-1600 \mathrm{~cm}^{-1}$ region are broader and somewhat stronger in relation to the $480 \mathrm{~cm}^{-1}$ band in the spectrum of leucothionine at $\mathrm{pH} 7$ than are those from thionine at $\mathrm{pH} 1.3$. In addition, a very weak band at $c a .455 \mathrm{~cm}^{-1}$ can 
Table II Band wavenumber $\left(\mathrm{cm}^{-1}\right)$ in SERS of thionine-modified gold electrode at $\mathrm{pH}$ 7 at two different potentials. Excitation wavelength $647.1 \mathrm{~nm}$.

\begin{tabular}{|c|c|c|}
\hline$+0.30 \mathrm{~V}$ & $-0.20 \mathrm{~V}$ & Open circuit $(+0.28 \mathrm{~V})$ \\
\hline 1615(s) & $\begin{array}{l}1615(\mathrm{sh}) \\
1595(\mathrm{sh})\end{array}$ & 1619(s) \\
\hline 1584(vw) & $\begin{array}{l}1589 \text { (w) } \\
1560 \text { (sh) } \\
1524(\mathrm{sh})\end{array}$ & \\
\hline 1498(s) & $1500(\mathrm{sh})$ & $1499(s)$ \\
\hline $1475(w-m)$ & 1479(m) & 1478(sh) \\
\hline 1424(sh) & & 1420 (sh) \\
\hline $\begin{array}{l}1388(\mathrm{vs}) \\
1340(\mathrm{vw})\end{array}$ & $\begin{array}{l}1393(\mathrm{sh}) \\
1350(\mathrm{~m})\end{array}$ & 1392(vs) \\
\hline $\begin{array}{l}1313(\mathrm{w}-\mathrm{m}) \\
1290(\mathrm{sh})\end{array}$ & $1314(\mathrm{sh})$ & $\begin{array}{l}1317(w) \\
1293(\text { sh) }\end{array}$ \\
\hline $\begin{array}{l}1240(w) \\
1225(w)\end{array}$ & $1245(\mathrm{~s})$ & \\
\hline $\begin{array}{l}1150(\mathrm{~m}) \\
1132(\mathrm{sh})\end{array}$ & $1156(\mathrm{~m})$ & $\begin{array}{l}1155(\mathrm{~m}) \\
1133(\mathrm{sh})\end{array}$ \\
\hline $1032(\mathrm{~m})$ & $1040(w)$ & $1038(\mathrm{~m})$ \\
\hline $1003(\mathrm{vw})$ & & $1003(\mathrm{vw})$ \\
\hline $961(\mathrm{vw})$ & $955(\mathrm{vw})$ & $960(\mathrm{vw})$ \\
\hline $906(\mathrm{~m})$ & $909(\mathrm{vw})$ & 908(w) \\
\hline $824(w)$ & & $830(w)$ \\
\hline $804(w)$ & & $808(\mathrm{sh})$ \\
\hline $757(\mathrm{vw})$ & & \\
\hline 672(w) & $670(\mathrm{vw})$ & $\begin{array}{l}738(v w) \\
677(w)\end{array}$ \\
\hline 611(s) & $\begin{array}{l}614(\mathrm{vw}) \\
577(\mathrm{vw})\end{array}$ & $\begin{array}{l}616(\mathrm{~m}) \\
570\end{array}$ \\
\hline 480 (vvs) & 481 (vs) & 481(vvs) \\
\hline $438(\mathrm{sh})$ & $439(\mathrm{~s})$ & $441(\mathrm{sh})$ \\
\hline 417(sh) & 419(sh) & 416(sh) \\
\hline 399(sh) & $402(\mathrm{sh})$ & \\
\hline $360(v w)$ & & \\
\hline $310(\mathrm{vw})$ & $312(w)$ & \\
\hline 294(vw) & & $298(v w)$ \\
\hline
\end{tabular}

Key: $\mathrm{s}=$ strong, $\mathrm{m}=$ medium, $\mathrm{v}=$ very, $\mathrm{sh}=$ shoulder, $\mathrm{w}=$ weak.

be distinguished in the Raman spectrum at $\mathrm{pH}$ 7. This band was not apparent in the leucothionine spectrum at $\mathrm{pH}$ 1.3.

\section{(c) $\mathrm{pH} 10$}

The Raman spectra of a thionine coated Au electrode at $\mathrm{pH} 10$ and at various applied potentials are shown in Figure 4. The wavenumbers 


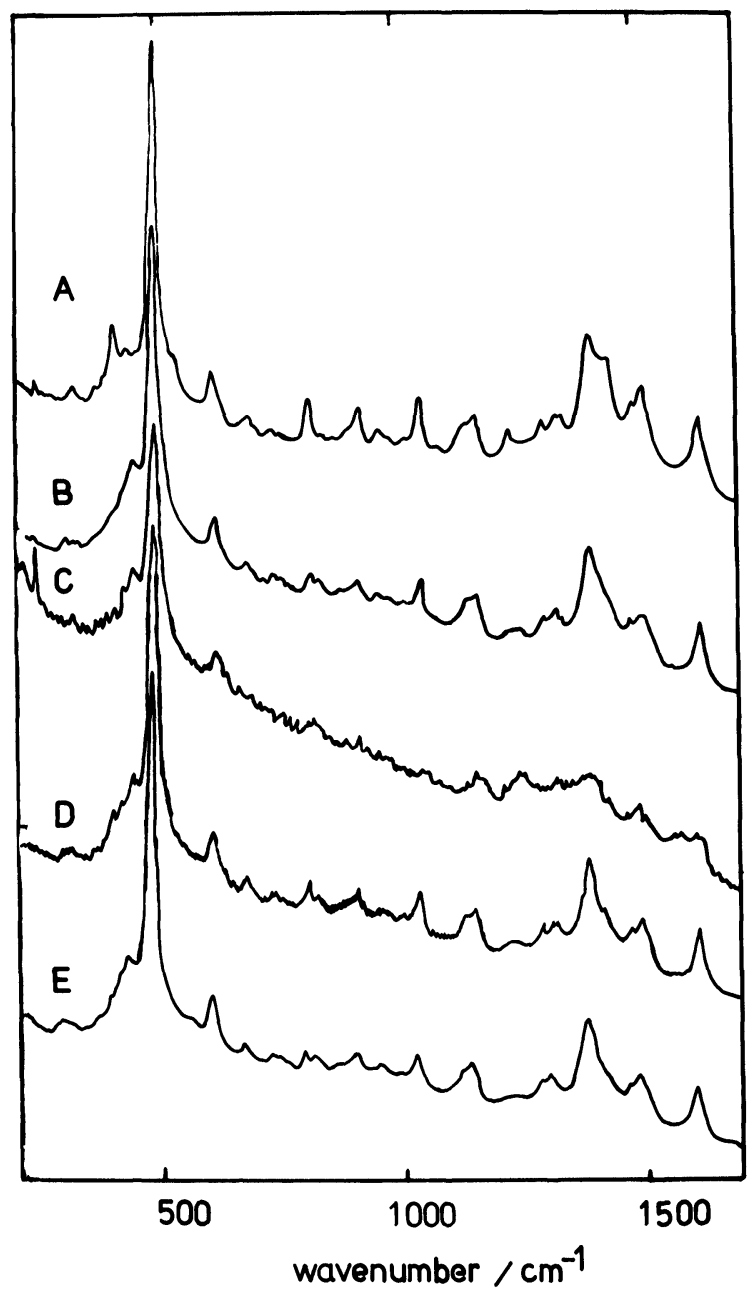

Figure 4 SERS of thionine-coated gold electrode, at $\mathrm{pH}=10$, at various applied potentials. (A) Open circuit potential $(+0.27 \mathrm{~V}) ;(\mathrm{B})+0.30 \mathrm{~V}$; (C) $+0.10 \mathrm{~V}$; (D) -0.10 $\mathrm{V} ;(\mathrm{E})-0.30 \mathrm{~V} ;(\mathrm{F})-0.50 \mathrm{~V}$. 
and the relative intensities of the bands observed in these spectra are given in Table III. As can be seen, these differ greatly from those measured at $\mathrm{pH} 1.3$ and 7. Here the overall Raman signal in all the spectra is down by a factor of 10 (these spectra were recorded on the 10 $\mathrm{k}$ counts s${ }^{-1}$ scale compared with the 100 to $200 \mathrm{k}$ counts s$^{-1}$ scale used for thionine spectra at $\mathrm{pH} 1.3$ and 7). The other striking difference observed is that there was no decrease in the overall Raman signal at applied potentials of -0.30 and $-0.50 \mathrm{~V}$ where the coated species should be in the leucothionine form (see Figure 3B).

Table III Band wavenumbers $\left(\mathrm{cm}^{-1}\right)$ in SERS of thionine-modified gold electrode at pH 10 at various applied potentials. Excitation wavelength, $647.1 \mathrm{~nm}$.

\begin{tabular}{|c|c|c|c|c|c|}
\hline $\begin{array}{l}\text { Open circuit } \\
\text { voltage } \\
(+27 \mathrm{~V})\end{array}$ & $+0.30 \mathrm{~V}$ & $+0.10 \mathrm{~V}$ & $-0.10 \mathrm{~V}$ & $-0.30 \mathrm{~V}$ & $-0.50 \mathrm{~V}$ \\
\hline $1612(\mathrm{~s})$ & 1609 (s) & $1608(s)$ & $1608(s)$ & $1609(\mathrm{~s})$ & $1608(s)$ \\
\hline 1590 (sh) & 1589(sh) & 1590 (sh) & 1589(sh) & $1587(\mathrm{sh})$ & $1587(\mathrm{sh})$ \\
\hline $1500(\mathrm{sh})$ & 1500 (sh) & $1500(\mathrm{sh})$ & $1500(\mathrm{sh})$ & 1499(sh) & $1500(\mathrm{sh})$ \\
\hline 1424(vvs) & 1419(vs) & 1419(vvs) & 1419(vvs) & 1424(vvs) & 1420 (vs) \\
\hline 1406 (sh) & 1403(vvs) & & & $1403(\mathrm{sh})$ & \\
\hline $1338(\mathrm{vw})$ & $1338(\mathrm{vw})$ & & $1337(\mathrm{vw})$ & $1340(\mathrm{vw})$ & $1337(\mathrm{vw})$ \\
\hline 1316(s) & 1312(s) & 1312(s) & $1313(\mathrm{~s})$ & 1313(s) & $1312(\mathrm{~s})$ \\
\hline $1228(\mathrm{~m})$ & $1226(\mathrm{~m})$ & $1226(\mathrm{~m})$ & $1227(\mathrm{~m})$ & $1230(\mathrm{~m})$ & $1231(\mathrm{~m})$ \\
\hline $1155(\mathrm{sh})$ & 1151(sh) & $1150(\mathrm{sh})$ & $1150(\mathrm{sh})$ & 1149(sh) & 1147 (sh) \\
\hline 1121(s) & $1118(\mathrm{~s})$ & $1116(\mathrm{~s})$ & $1117(\mathrm{~s})$ & 1119 (s) & $1116(\mathrm{~s})$ \\
\hline $1062(w)$ & $1060(w)$ & $1060(w)$ & 1058(w) & $1062(w)$ & $1056(w)$ \\
\hline $1030(\mathrm{~m})$ & $1026(\mathrm{~m})$ & $1027(\mathrm{~m})$ & $1027(\mathrm{~m})$ & 1027(m) & $1022(\mathrm{~m})$ \\
\hline $1003(\mathrm{vw})$ & & 1004(vw) & 1003(vw) & $1003(\mathrm{vw})$ & \\
\hline $946(w)$ & $940(w)$ & $940(\mathrm{w})$ & $940(\mathrm{w})$ & $940(\mathrm{w})$ & $937(\mathrm{vw})$ \\
\hline 911(w) & $908(w)$ & $908(w)$ & $908(w)$ & $908(w)$ & $908(w)$ \\
\hline $890(\mathrm{sh})$ & 888(sh) & 888(sh) & $887(w)$ & $891(w)$ & 885 (sh) \\
\hline $855(\mathrm{vw})$ & $854(\mathrm{vw})$ & $855(\mathrm{vw})$ & $851(\mathrm{vw})$ & $854(\mathrm{vw})$ & $855(\mathrm{vw})$ \\
\hline $830(\mathrm{vw})$ & & & & $828(\mathrm{vw})$ & \\
\hline $808(\mathrm{vw})$ & $807(\mathrm{vw})$ & $806(\mathrm{vw})$ & $805(w)$ & $808(\mathrm{vw})$ & $806(w)$ \\
\hline $746(\mathrm{vw})$ & & $746(\mathrm{vw})$ & $742(\mathrm{vw})$ & $744(\mathrm{vw})$ & \\
\hline $722(\mathrm{vw})$ & $721(\mathrm{vw})$ & 720 (vw) & $722(\mathrm{vw})$ & $723(\mathrm{vw})$ & $725(\mathrm{vw})$ \\
\hline $680(w)$ & $681(w)$ & $680(w)$ & $680(w)$ & $675(w)$ & $680(\mathrm{vw})$ \\
\hline 612(s) & $616(s)$ & $609(\mathrm{~s})$ & $609(\mathrm{~s})$ & $608(s)$ & $608(\mathrm{~m})$ \\
\hline 579(sh) & $580(\mathrm{sh})$ & $582(\mathrm{sh})$ & $580(\mathrm{sh})$ & $581(\mathrm{sh})$ & $580(\mathrm{sh})$ \\
\hline 481(vs) & 479(vs) & 478(vs) & 480 (vs) & 478(vvs) & $\begin{array}{l}478(\mathrm{vvs}) \\
448(\mathrm{sh})\end{array}$ \\
\hline $427(s)$ & $426(s)$ & $424(s)$ & $425(\mathrm{~s})$ & $425(\mathrm{~s})$ & $424(s)$ \\
\hline 313(vw) & $310(v w)$ & 312(vw) & $312(\mathrm{vw})$ & $310(v w)$ & $310(v w)$ \\
\hline $292(\mathrm{vw})$ & & & & $290(\mathrm{vw})$ & \\
\hline
\end{tabular}

Key: $\mathrm{s}=$ strong, $\mathrm{m}=$ medium, $\mathrm{v}=$ very, $\mathrm{sh}=$ shoulder, $\mathrm{w}=$ weak. 
At $\mathrm{pH} 10$ the most prominent feature in the Raman spectra of coated thionine is no longer observed at $480 \mathrm{~cm}^{-1}$, as was the case at $\mathrm{pH} 1.3$ and 7 . Here, all the spectra are dominated by the complex band structure centred at $c a .1420 \mathrm{~cm}^{-1}$. This band appears as an unresolved doublet at the open circuit potential ( $+0.27 \mathrm{~V}$, spectrum A in Figure 4) with components at 1424 and $1406 \mathrm{~cm}^{-1}$. At an applied potential of $+0.30 \mathrm{~V}$ (spectrum $\mathrm{B}$ in Figure 4) this band also has a doublet structure with peaks centred at 1419 and $1403 \mathrm{~cm}^{-1}$. On changing the applied potential to $+0.10 \mathrm{~V}$ (spectrum $\mathrm{C}$ in Figure 4) only a broad band centred at $1419 \mathrm{~cm}^{-1}$ is apparent. Similarly when the applied potential is switched to $0.10 \mathrm{~V}$ (spectrum D in Figure 4) again only one band, centred at $1419 \mathrm{~cm}^{-1}$, is observed. At an applied potential of $-0.30 \mathrm{~V}$ again a shoulder appears at $1403 \mathrm{~cm}^{-1}$, with the main band centred at $1424 \mathrm{~cm}^{-1}$.

At $\mathrm{pH} 1.3$ and 7, there are two bands, at 1390 and $1425 \mathrm{~cm}^{-1}$, observed in the Raman spectra of thionine. The band at $1390 \mathrm{~cm}^{-1}$ also appears in the resonance Raman spectrum of solid thionine and has been assigned to the asymmetric $\mathrm{CN}$ stretching mode of the thionine molecule. The band at 1425 appears only in the Raman spectra of coated thionine and has been attributed to the asymmetric stretching vibration of the $\mathrm{CNC}$ bond bridging the two thionine molecules in the dimer formed on the electrode surface. These wavenumber shifts for the asymmetric $\mathbf{C}-\mathrm{N}$ stretching vibrational mode are higher than those expected for secondary amines ${ }^{15}$ and may be explained on the basis of the higher bond order and/or some mode mixing. ${ }^{10}$

At $\mathrm{pH} 10$ the $1390 \mathrm{~cm}^{-1}$ band shifts up to $1400-1420 \mathrm{~cm}^{-1}$. This shift suggests an increase in the $\mathrm{CN}$ double bond character in the thionine molecule.

The band at $1618 \mathrm{~cm}^{-1}$, assigned to a CC stretching vibration ${ }^{10}$ in the Raman spectra of coated thionine at $\mathrm{pH} 1.3$ and 7, shifts down to 1612 $\mathrm{cm}^{-1}$ on changing the $\mathrm{pH}$ of the supporting electrolyte solution to 10 , and a shoulder at $c a .1590 \mathrm{~cm}^{-1}$ is apparent at this $\mathrm{pH}$. This $1590 \mathrm{~cm}^{-1}$ band is not apparent in the Raman spectra of thionine at $\mathrm{pH} 1.3$ and 7, but there is a band seen at 1581 and $1589 \mathrm{~cm}^{-1}$ in the spectra of leucothionine at these $\mathrm{pH}$ values. At $\mathrm{pH} 10$, the $1612 \mathrm{~cm}^{-1}$ band shifts to $1609 \mathrm{~cm}^{-1}$ on applying a potential of $+0.30 \mathrm{~V}$ but does not shift at other values of applied potential.

There is a marked increase in the relative intensity of the band at $1312-1316 \mathrm{~cm}^{-1}$ in the spectrum of coated thionine at $\mathrm{pH} 10$. This band 
appears as a weak feature at $1313-1320 \mathrm{~cm}^{-1}$ in the spectra at $\mathrm{pH} 1.3$ and 7. There is an additional weak band which appears at $1340 \mathrm{~cm}^{-1}$ in the spectrum at $\mathrm{pH} 10$. The band at $1226-1230 \mathrm{~cm}^{-1}$ shows a marked increase in relative intensity compared with the similar band at 1223$1240 \mathrm{~cm}^{-1}$ seen in the Raman spectra at $\mathrm{pH} 1.3$ and 7.

There are changes in the relative intensities and positions of two bands observed in $1100-1150 \mathrm{~cm}^{-1}$ region of the Raman spectrum on changing the $\mathrm{pH}$ of the electrolyte solution to 10 . At $\mathrm{pH} 1.3$ and 7 the two bands are observed at $c a .1130$ and $1150 \mathrm{~cm}^{-1}$ with the latter band more intense than the former. However, at $\mathrm{pH} 10$ the dominant band appears at $1116-1120 \mathrm{~cm}^{-1}$ with a shoulder at $1147-1155 \mathrm{~cm}^{-1}$. Again there is a marked increase in the relative intensities of these two bands compared with those of the corresponding bands at $\mathrm{pH} 1.3$ and 7 . The band at $1130 \mathrm{~cm}^{-1}$ in the spectrum of coated thionine at $\mathrm{pH} 1.3 \mathrm{has}$ been assigned to a $S=O$ vibration resulting from the oxidation of the $S$ atom of thionine during the electro-coating process..$^{10} \mathrm{~A}$ new band at $1060 \mathrm{~cm}^{-1}$ is observed in the spectrum of coated thionine at $\mathrm{pH} 10$. This band was not apparent in the spectra at $\mathrm{pH} 1.3$ or 7 . The band in the region $1023-1030 \mathrm{~cm}^{-1}$ at $\mathrm{pH} 10$ is at a lower wavenumber than the corresponding band of thionine at $\mathrm{pH} 1.3$ and 7 , i.e. $1036-1040 \mathrm{~cm}^{-1}$. Similarly there is a shift to lower wavenumber of the band observed at $950-980 \mathrm{~cm}^{-1}$ at $\mathrm{pH} 1.3$ and 7 . At $\mathrm{pH} 10$ this band appears at 937-946 $\mathrm{cm}^{-1}$.

Other major differences in the Raman spectra of coated thionine at pH 10 are observed in the $400-500 \mathrm{~cm}^{-1}$ region. Here, as in the case of the spectra at $\mathrm{pH} 1.3$ and 7 , the strongest band is at $480 \mathrm{~cm}^{-1}$. However, only a single strong and relatively broad band is observed at $424-427 \mathrm{~cm}^{-1}$. In the Raman spectra of thionine at $\mathrm{pH} 1.3$ and 7 , at least three bands, at ca. 440,420 and $400 \mathrm{~cm}^{-1}$, were apparent. There is a marked increase in relative intensity of the band at $424-427 \mathrm{~cm}^{-1}$ at pH 10.

The large changes in band wavenumbers and intensities observed in the Raman spectra on raising the $\mathrm{pH}$ of the electrolyte solution to $\mathrm{pH}$ 10 suggest major changes in both the molecular structure and the absorption spectrum of coated thionine. The decrease in the overall Raman signal suggests some loss of resonance enhancement which could arise from a shift in the absorption spectrum. As with the leucothionine spectra, the spectra obtained at $\mathrm{pH} 10$ appear to be attributable mainly to SERS effects. 
Thionine in solution exists in various protonated forms ${ }^{16,17}$ depending on the $\mathrm{pH}$. For example, at $\mathrm{pH}<2$ thionine exists in its diprotonated form, which absorbs strongly at $673 \mathrm{~nm}$. In the $\mathrm{pH}$ range 2 to 10 , the monoprotonated form is dominant with a strong absorption at 597 $\mathrm{nm}$. In strongly alkaline solution $(5 \% \mathrm{NaOH})$ a basic form ${ }^{16}$ exists, with an absorption band at $515 \mathrm{~nm}$. The transition between the monoprotonated form and thionine hydroxide is reported to occur at $\mathrm{pH} 11 .{ }^{16}$

The Raman spectra of the thionine modified gold electrode at $\mathrm{pH} 10$ may be attributed to thionine hydroxide. The transition from protonated thionine to thionine hydroxide on the electrode surface appears to take place at lower $\mathrm{pH}$ than that reported for the solution species, but no absorption data are available in the literature for thionine modified electrodes at different $\mathrm{pH}$ values.

\section{Acknowledgements}

We are grateful to the SERC for support of this work.

\section{References}

1. W. J. Albery and A. R. Hillman, Annual Reports C75 (The Royal Society of Chemistry, London, 1981) p. 377.

2. R. W. Murray, Phil. Trans. Roy. Soc. London. Ser. A302, 253 (1981).

3. W. J. Albery, Acc. Chem. Res. 15, 142 (1982).

4. W. J. Albery, A. W. Faulds and A. R. Hillman, J. Electrochem. Soc. 127, 654 (1980).

5. W. J. Albery, W. R. Bowen, F. Fisher, A. W. Faulds, K. J. Hall, A. R. Hillman, R. G. Edgell and A. R. Orchard, J. Electroanal. Chem. 107, 37 (1980).

6. W. J. Albery, A. W. Faulds, K. J. Hall, A. R. Hillman, R. G. Edgell and A. F. Orchard, Nature 282, 793 (1979).

7. J. M. Boulderey and M. D. Archer, Electrochim. Acta 28, 1575 (1983).

8. W. J. Albery, M. G. Boutelle, P. J. Colby and A. R. Hillman, J. Electroanal. Chem. 133, 135 (1982).

9. W. J. Albery, A. R. Hillman, R. G. Edgell and M. Nutton, J. Chem. Soc. Faraday Trans. 1 80, 111 (1984).

10. K. Hutchinson, R. E. Hester, W. J. Albery and A. R. Hillman, J. Chem. Soc. Faraday Trans. 1 80, 2053 (1984).

11. P. Gao, M. L. Patterson, M. A. Tadyyoni and M. J. Weaver, Langmuir 1, 173 (1985).

12. P. Gao and M. J. Weaver, J. Phys. Chem. 89, 5040 (1985).

13. M. L. Patterson and M. J. Weaver, J. Phys. Chem. 89, 5046 (1985).

14. H. R. Virdee and R. E. Hester, Croat. Chim. Acta, 61, 355 (1988).

15. F. R. Dollish, W. G. Fately and F. F. Bentley, Characteristic Raman Frequencies of Organic Compounds, Wiley-Interscience, New York, 1974.

16. L. F. Epstein, F. Karush and E. Robinowitch, J. Opt. Soc. Am. 31, 77 (1941).

17. E. Rabinowitch and L. F. Epstein, J. Am. Chem. Soc. 63, 69 (1941).

18. E. Rabinowitch, J. Chem. Phys. 8, 551 (1940). 